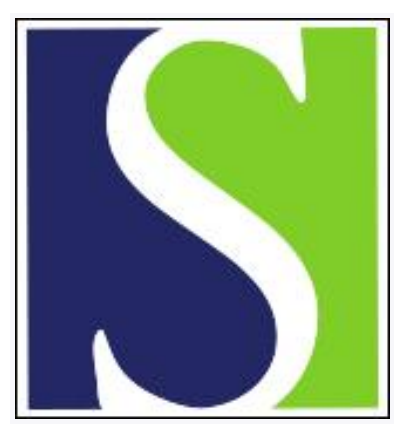

Scand J Work Environ Health 1989;15(5):329-334

https://doi.org/10.5271/sjweh.1842

Issue date: Oct 1989

Effect of duration of employment in piecework on severe disability among female garment workers.

by Brisson $C$, Vinet A, Vezina M, Gingras S

Affiliation: Department of Social and Preventive Medicine, Laval University, Quebec, Canada.

This article in PubMed: www.ncbi.nlm.nih.gov/pubmed/2799319

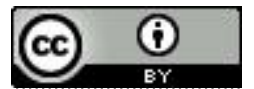




\title{
Effect of duration of employment in piecework on severe disability among female garment workers
}

\author{
by Chantal Brisson, MA, MSc, ${ }^{1,2}$ Alain Vinet, PhD, ${ }^{2,3}$ Michel Vézina, MD, MPH, ${ }^{1,2,4}$ \\ Suzanne Gingras, MSc ${ }^{1,2}$
}

\begin{abstract}
BRISSON C, VINET A, VÉZINA M, GINGRAS S. Effect of duration of employment in piecework on severe disability among female garment workers. Scand $J$ Work Environ Health 1989;15:329-334. This study measured the association between duration of employment in piecework and the prevalence of severe disability among 533 Quebec female garment workers who left employment between 1976 and 1985 . Yearly information regarding occupational characteristics was available from a public agency for the 30-year period 1956-1985. Information on disability status was collected in a personal interview. Duration of employment in piecework was associated with the prevalence of severe disability. A multivariate analysis found that the association was independent of age, smoking habits, education, type of task and total length of employment. Workers who spent $5-9,10-14,15-19$, and $\geq 20$ years in piecework had an increased prevalence of severe disability in comparison with the base-line category of $0-4$ years. The adjusted risk ratios were 2.2 [95\% confidence interval $(95 \% \mathrm{CI}) 1.0-4.6], 3.3(95 \% \mathrm{CI} 1.5-6.9), 3.6(95 \% \mathrm{CI}$ $1.5-8.4)$, and $2.3(95 \% \mathrm{CI} 0.8-6.6)$, respectively. The association was particularly strong for disability due to musculoskeletal problems and disability due to cardiovascular disorders although small numbers were involved.
\end{abstract}

Key terms: chronic disease, clothing industry, musculoskeletal disorders, psychological stress, occupation, stress, textile industry, women.

This is the second of two papers on long-term disability among female garment workers. The first showed an increased prevalence of severe disability relative to the corresponding prevalence for women employed in other occupations (1). In the present study we investigated the determinants of severe disability within the cohort of garment workers.

About one-half of the women employed in the Québec garment industry receive a piecework remuneration (2). In other Canadian industries, such as textile, rubber, furniture, shoe, and garment manufacturing, a relatively large proportion of the work force is estimated to be employed in various systems of piecework (3). Therefore, the exposure of interest in the present study was the time pressure experienced by workers doing piecework, a type of paced work in which the employee is paid according to the number of units produced. The term "paced work" refers more generally to any job in which human or physical constraints determine the time in which a given task, and generally a specific quantity of production has to be accomplished by a worker (4). In addition to a high time pres-

1 Department of Social and Preventive Medicine, Laval University, Quebec, Canada.

2 Interdisciplinary Research Group on Work Organization, Health and Safety, Laval University, Quebec, Canada.

3 Department of Industrial Relations, Laval University, Quebec, Canada.

4 Department of Community Health, Laval University Hospital, Quebec, Canada.

Reprint requests to: Ms C Brisson, Départment de médecine sociale et préventive, Université Laval, Québec, PQ Canada GIK 7P4. sure these jobs may involve repetitive motion and monotony.

While piecework has often been associated with a higher frequency of occupational injuries (5), little is known about the adverse chronic health effects possibly associated with this form of time pressure. Three experimental studies have assessed the health effects of piecework among factory and clerical workers by comparing the level of urinary catecholamine excretion of workers paid by piecework to that of workers in the same job paid an hourly wage $(6-8)$. All three studies found a higher level of catecholamine excretion among the workers paid by piecework. Catecholamine excretion is usually considered a good biological indicator of the level of arousal in the presence of a stressor (9). However, the meaning of such an indicator in terms of future health effects remains largely unknown. Levi (7) suggested that workers paid by piecework may be more likely to deny their symptoms. Pieceworkers may be less inclined to adapt their pace when they experience pain or fatigue because of the monetary consequence of slowing down. This situation could lead to the accumulation of tension and fatigue and progress toward long-term adverse health effects.

Some cross-sectional studies have evaluated the health problems associated with other forms of paced work (eg, machine-paced work, assembly-line work, computerized control of individual production). One often-cited study of 2010 workers by Caplan et al (10) found that assembly-line workers had higher levels of depressive symptoms and somatic complaints (sleeping difficulties, digestive problems, loss of appetite, 
elevated heart rate, and sweating palms) than 23 other occupational categories of blue-collar and white-collar workers. They also had the second highest level of anxiety and the third highest level of irritation symptoms. Results in line with these previous findings have been reported when paced work was studied in automobile manufacturing (11), inspection on an assemblyline $(12,13)$, fish processing (14), and service industries [eg, telephone operation (15) and data entry (16, 17)].

Our previous study showed that garment workers who had left employment had an increased prevalence of severe disability compared with workers formerly employed in other occupations (1). We hypothesized that the time pressure induced by piecework, when accumulated over several years, had contributed to the development of disabling conditions among the garment workers. The purpose of the current study was thus to determine whether duration of employment in piecework was associated with the prevalence of severe disability within the cohort of garment workers.

\section{Subjects and methods}

The Quebec women's garment industry is composed of more than 500 small factories, each employing about 20-30 workers. Ninety percent of these factories are in the Montreal area. Sewing-machine operators in the various factories manufacture the same products (women's garments) with similar equipment. Little automation is used in women's garment manufacturing because of the rapidly changing models and fabrics. All factories tend to be concentrated in one industrial area of the city and located in similar buildings. Employee turnover is high in the industry; $55 \%$ of the sewing-machine operators in our study were employed in three or more different factories during their worklife. Some differences may exist between factories in terms of dust, noise, light, and posture. However, site visits indicated that environmental factors did not appear to be systematically different in the factories using a piecework system as compared with factories using an hourly wage system. Thus it was possible to study the effect of piecework among workers doing essentially the same job in a comparable environment. The inclusion criteria have been defined in our first paper (1). Given the focus on severe disability, the present study was restricted to workers who had left employment at the time of the interview $(\mathrm{N}=533)$.

Various systems of piecework are used in different industries (18). They can be classified according to the proportion of the salary dependent on the number of units produced. Piecework systems can also be classified according to the type of rate given by unit produced. The rate can be fixed, but it can also decrease or increase above a certain number of units produced. In the present study group, $100 \%$ of each worker's salary was dependent on the quantity produced, according to a fixed rate per unit.
The classification of exposure to piecework was based on the number of years in piecework between 1956 and 1985. All occupational data were abstracted from records kept by the Comité paritaire du vêtement pour dames (Women's Garment Joint Committee). These records contained a complete work history for each worker. This public agency is administered jointly by the government, employers, and union representatives and is in charge of enforcing laws regarding wages and workhours in the garment industry. The information is provided monthly by the employers. Inspectors review the information regularly (on-site spot-checking) and in response to workers' complaints. The same data have been collected and stored in a similar manner by the Comité paritaire du vêtement pour dames since 1955.

One record per worker per year was available. Each record contained a code for employer, job title, payment status (piecework versus hourly wage), the number of workhours, and the type of task. The repetitive tasks were defined as those involving sewing only a section of each garment and nonrepetitive tasks involved sewing the whole garment. Because of the incompleteness of the records, information regarding type of task was obtained by interview for 1980-1985. Exposure and other work characteristics were computed for years in which the worker was employed more than $1000 \mathrm{~h}$ to standardize the intensity of exposure between categories.

Severe disability was defined as one or more disabling conditions which prevented employment or the conduct of housework for the 12 months preceding the interview. Data regarding disability status, smoking, and sociodemographic characteristics were collected by interview. A full description of the disability indicator and the data collection has been presented in our previous paper (1).

The first step of the analysis entailed an analysis of the prevalence of disability from all causes by occupational characteristics, education, and smoking status. Risk ratios and $95 \%$ Taylor-series confidence intervals (19) were computed. A multivariate binomial regression (20) was performed to estimate the association between disability and duration of employment in piecework (and the variance of the estimates) while potential confounders such as age, smoking status, education, type of task, and total length of employment were controlled for. Potential confounders were assessed with the use of a backward elimination strategy, and they were retained in the model when their exclusion resulted in a change of $15 \%$ or more in the effect estimates. The second level of analysis focused on disability due to three groups of causes, ie, musculoskeletal [International Classification of Diseases (ICD) 710-739], cardiovascular (ICD 400-459), and other disorders combined (21). Analyses were performed with the statistical analysis system (22) and with the generalized linear interactive modeling system (23). 


\section{Results}

The study population was composed of 533 female sewing-machine operators; this number represents $79.5 \%$ of the eligible population. The overall prevalence of severe disability was $18.6 \%$. Details of the population base, eligible population, response rate, and a general description of the prevalence of disability have been presented in our previous paper (1).

Table 1 shows the crude risk ratios for various occupational characteristics, education, and smoking status. The prevalence of disability increased with the duration of employment in piecework. A small increase in the risk ratio was observed for smokers and lesseducated workers.

The regression analysis showed that the association with duration of employment in piecework was confirmed after adjustment for age, smoking, total length of employment, and proportion of years in repetitive tasks. Workers who spent $5-9,10-14,15-19$ and $\geq 20$ years in piecework had adjusted risk ratios of 2.2 , $3.3,3.6$, and 2.3 , respectively, compared with the baseline category of $0-4$ years in piecework (table 2).

We conducted a separate analysis for disability due to specific causes. Duration of employment in piecework was associated with musculoskeletal disability and, but perhaps to a less extent, with cardiovascular disability. There was no association with all other causes combined, and no other specific cause had sufficient numbers to warrant a separate analysis. The results remained essentially the same after confounders were controlled for, but the small numbers produced unstable effect estimates (table 2).

\section{Discussion}

This study examined the long-term effect of a specific form of time-related work pressure. Several crosssectional studies have measured the short-term symptoms or changes associated with garment assembly and various forms of paced work. However, this is the first time that the long-term adverse health effects have been directly investigated. The study design involved the following advantages over a cross-sectional study: (i) the study population consisted of workers who had left employment during the last 10 years; (ii) if the deceased cases are excluded and given that the withdrawal from employment is assumed to be permanent, the prevalence of disability represents the cumulative incidence of disability for the 10-year study period (1976-1985); (iii) the cumulative exposure to piecework and other occupational characteristics were measured retrospectively with objective records over the 30 -year period preceding the interview.

The study used a self-reported indicator of disability. The limitations related to this indicator have been discussed in our previous paper (1). Neither the exposure status of the subject nor the exact hypothesis of the study was known by the interviewers and interviewees, and public and observable behaviors were reported which reduced the possibility of reporting bias. In addition, a self-reported cause of disability is a valid source of information with which to identify broad classes of disease like those used in this study. This assumption is supported by Warren's finding (24) that the ability of impaired persons to report the un-

Table 1. Risk ratios for severe disability by occupational characteristics, education, and smoking status.

\begin{tabular}{|c|c|c|c|c|c|}
\hline & \multirow{2}{*}{$\begin{array}{c}\text { Total } \\
\text { number of } \\
\text { workers }\end{array}$} & \multicolumn{2}{|c|}{ Severe disability } & \multirow{2}{*}{$\begin{array}{l}\text { Risk } \\
\text { ratio }\end{array}$} & \multirow{2}{*}{$\begin{array}{c}95 \% \\
\text { confidence } \\
\text { interval }\end{array}$} \\
\hline & & $\mathrm{N}$ & $\%$ & & \\
\hline \multicolumn{6}{|l|}{ Years in piecework } \\
\hline $\begin{array}{l}0-4 \\
5-9 \\
10-14 \\
15-19 \\
\geq 20\end{array}$ & $\begin{array}{r}94 \\
108 \\
124 \\
126 \\
81\end{array}$ & $\begin{array}{r}9 \\
20 \\
31 \\
32 \\
12\end{array}$ & $\begin{array}{r}9.6 \\
18.5 \\
25.0 \\
25.4 \\
14.8\end{array}$ & $\begin{array}{l}1.0 \\
1.9 \\
2.6 \\
2.7 \\
1.5\end{array}$ & $\begin{array}{l}0.9-4.0 \\
1.4-5.0 \\
1.4-5.0 \\
0.7-3.5\end{array}$ \\
\hline \multicolumn{6}{|l|}{ Total length of employment (years) } \\
\hline $\begin{array}{l}5-9 \\
10-14 \\
15-19 \\
\geq 20\end{array}$ & $\begin{array}{r}90 \\
150 \\
132 \\
161\end{array}$ & $\begin{array}{l}13 \\
31 \\
36 \\
24\end{array}$ & $\begin{array}{l}14.4 \\
20.7 \\
27.3 \\
14.9\end{array}$ & $\begin{array}{l}1.0 \\
1.4 \\
1.9 \\
1.0\end{array}$ & $\begin{array}{l}0.8-2.6 \\
1.1-3.3 \\
0.6-2.0\end{array}$ \\
\hline \multicolumn{6}{|l|}{ Years in repetitive task ( $\%$ of total) } \\
\hline $\begin{array}{l}0 \\
1-49 \\
50-99 \\
100\end{array}$ & $\begin{array}{r}282 \\
117 \\
72 \\
62\end{array}$ & $\begin{array}{l}61 \\
21 \\
12 \\
10\end{array}$ & $\begin{array}{l}21.6 \\
18.0 \\
16.7 \\
16.1\end{array}$ & $\begin{array}{l}1.0 \\
0.8 \\
0.8 \\
0.8\end{array}$ & $\begin{array}{l}0.5-1.3 \\
0.4-1.3 \\
0.4-1.4\end{array}$ \\
\hline \multicolumn{6}{|l|}{ Education (years) ${ }^{a}$} \\
\hline $\begin{array}{l}1-5 \\
6-13\end{array}$ & $\begin{array}{l}115 \\
414\end{array}$ & $\begin{array}{l}28 \\
76\end{array}$ & $\begin{array}{l}24.4 \\
18.4\end{array}$ & $\begin{array}{l}1.3 \\
1.0\end{array}$ & $0.9-2.0$ \\
\hline \multicolumn{6}{|l|}{ Smoking status ${ }^{b}$} \\
\hline $\begin{array}{l}\text { Occasional smokers and nonsmokers } \\
\text { Smokers and ex-smokers }\end{array}$ & $\begin{array}{l}276 \\
243\end{array}$ & $\begin{array}{l}47 \\
52\end{array}$ & $\begin{array}{l}17.0 \\
21.4\end{array}$ & $\begin{array}{l}1.0 \\
1.3\end{array}$ & $0.9-1.8$ \\
\hline
\end{tabular}

a Four unknown.

b Fourteen unknown. 
Table 2. Adjusted risk ratios for severe disability from specific causes by duration of employment in piecework.

\begin{tabular}{|c|c|c|c|c|}
\hline Cause of disability & $\begin{array}{c}\text { Number } \\
\text { of } \\
\text { workers }\end{array}$ & $\begin{array}{c}\text { Cases } \\
\text { of } \\
\text { disability }\end{array}$ & Risk ratio & $\begin{array}{c}95 \% \\
\text { confidence } \\
\text { interval }\end{array}$ \\
\hline \multicolumn{5}{|l|}{ Specific causes ${ }^{b}$} \\
\hline \multicolumn{5}{|l|}{ Musculoskeletal diseases } \\
\hline $\begin{array}{l}0-4 \text { years in piecework } \\
5-9 \text { years in piecework } \\
10-14 \text { years in piecework } \\
15-19 \text { years in piecework } \\
\geq 20 \text { years in piecework }\end{array}$ & $\begin{array}{r}94 \\
108 \\
124 \\
126 \\
81\end{array}$ & $\begin{array}{r}1 \\
5 \\
12 \\
8 \\
5\end{array}$ & $\begin{array}{r}1.0 \\
4.3 \\
10.0 \\
8.0 \\
11.4\end{array}$ & $\begin{array}{l}0.5-35.9 \\
1.0-79.3 \\
0.8-76.8 \\
0.9-137.1\end{array}$ \\
\hline \multicolumn{5}{|l|}{ Cardiovascular diseases } \\
\hline $\begin{array}{l}0-4 \text { years in piecework } \\
5-9 \text { years in piecework } \\
10-14 \text { years in piecework } \\
15-19 \text { years in piecework } \\
\geq 20 \text { years in piecework }\end{array}$ & $\begin{array}{r}94 \\
108 \\
124 \\
126 \\
81\end{array}$ & $\begin{array}{l}1 \\
5 \\
5 \\
7 \\
4\end{array}$ & $\begin{array}{l}1.0 \\
5.1 \\
4.8 \\
6.8 \\
6.3\end{array}$ & $\begin{array}{l}0.6-43.6 \\
0.5-44.2 \\
0.7-71.1 \\
0.5-85.3\end{array}$ \\
\hline \multicolumn{5}{|l|}{ Other diseases } \\
\hline $\begin{array}{l}0-4 \text { years in piecework } \\
5-9 \text { years in piecework } \\
10-14 \text { years in piecework } \\
15-19 \text { years in piecework } \\
\geq 20 \text { years in piecework }\end{array}$ & $\begin{array}{r}94 \\
108 \\
124 \\
126 \\
81\end{array}$ & $\begin{array}{r}7 \\
9 \\
13 \\
17 \\
2\end{array}$ & $\begin{array}{l}1.0 \\
1.2 \\
1.6 \\
2.0 \\
0.0\end{array}$ & $\begin{array}{l}0.4-3.3 \\
0.6-4.5 \\
0.6-6.7 \\
0.0-5901\end{array}$ \\
\hline \multicolumn{5}{|l|}{ All causes } \\
\hline $\begin{array}{l}0-4 \text { years in piecework } \\
5-9 \text { years in piecework } \\
10-14 \text { years in piecework } \\
15-19 \text { years in piecework } \\
\geq 20 \text { years in piecework }\end{array}$ & $\begin{array}{r}94 \\
108 \\
124 \\
126 \\
81\end{array}$ & $\begin{array}{r}9 \\
20 \\
31 \\
32 \\
12\end{array}$ & $\begin{array}{l}1.0 \\
2.2 \\
3.3 \\
3.6 \\
2.3\end{array}$ & $\begin{array}{l}1.0-4.6 \\
1.5-6.9 \\
1.5-8.4 \\
0.8-6.6\end{array}$ \\
\hline
\end{tabular}

a Adjusted by binomial regression for age, smoking status, type of task, and total length of employment.

b Three cases had an unknown cause.

derlying medical condition is as high as $94 \%$ when compared with general practitioner's assessments.

The main limitation of our external comparison involved the possible bias due to differences in job requirements. However, in the present study, this limitation was overcome since this factor was controlled by the nature of the study population. The compared workers had all been employed in the garment industry, and they lived in the same metropolitan area. Therefore, their employment opportunity either in piecework or hourly wage jobs in garment manufacturing or in other industries, along with their job requirements, had been relatively similar. In addition, educational level was controlled in the analysis, and this procedure minimized bias due to differences in qualification.

Duration of employment in piecework was associated with the prevalence of disability. The association was independent of age, smoking status, education, type of task, and total length of employment. The data thus showed that the prevalence of disability was specifically associated with duration of employment in piecework among workers previously employed as sewing-machine operators for similar durations.

Our results are compatible with findings of previous cross-sectional studies of garment workers (25-29) and other groups of paced workers $(6-8,10-17,30)$, which found a high frequency of physiological, musculoskeletal, and psychological symptoms. More specifically, the association with musculoskeletal disability is compatible with the previous finding of a higher incidence of disability pensions due to musculoskeletal disorders among slaughterhouse workers (work which also involves fast pacing) when compared with the general population (31).

Among the 31 musculoskeletal disability cases, 19 were arthritic disorders (ICD 714-719), seven were back disorders (ICD 720-724), and the remaining five cases were dispersed among other categories or were unspecified. In another section of our questionnaire, a proportion of 58 to $77 \%$ of the women reported regular pain in the following sites: (i) lower back, (ii) upper back and neck, (iii) shoulders, (iv) hands, wrists or elbows, and (v) knees or ankles. All but one of these women had at least one regularly painful site.

A high prevalence of musculoskeletal disorders is compatible with the biomechanical stressors involved in a sewing-machine operator's job. The most frequent type of arthritic disorder, osteoarthritis, is possibly associated with wear-and-tear on joints (32). This conclusion is supported by prevalence studies which have shown specific affected sites in various occupational groups (elbows and knees in miners, fingers in cotton pickers, and fingers, elbows and knees in dock workers) (32). In addition, two postural characteristics of sewing-machine operators' jobs (working in the same position for a long period of time, including prolonged sitting and bent-over position, and repetitive work) are two of the six most important work-related factors associated with absence from work due to low-back pain 
(32). Finally, repetitive hand motions are associated with soft-tissue disorders in garment manufacturing (29).

The fact that musculoskeletal disability was specifically associated with duration of employment in piecework among the sewing-machine operators who had performed identical tasks suggests a combined effect of the time pressure induced by piecework and the biomechanical stressors involved in performing the task. Ergonomic studies $(26,30)$ have suggested a possibly related phenomenon of a more bent and more rigid posture when time pressure intensifies.

In conclusion, the data show that the duration of employment in piecework was associated with an increased prevalence of severe disability among garment workers. The association was particularly high for disability due to musculoskeletal disorders and for cardiovascular disability, although small numbers were involved. For musculoskeletal disability, one possible mechanism could be the combined effect of the biomechanical stressors involved in performing the task and the time pressure induced by piecework. Further research is needed to determine whether or not pieceworkers in other industries and other groups of high-paced workers also experience disabling conditions and to investigate the possible mechanisms.

\section{Acknowledgments}

This research was funded by grant 6605-2432-4Z from the National Health Research and Development Program of Canada.

We thank the Comite paritaire du vêtement pour dames for giving access to their files. We are grateful to Dr D Loomis, Dr N Pearce, Dr L Punnet, Dr D Savitz, and Ms M Casper for their critical review of the manuscript. We also thank Mr K Mundt, Dr C Shy, Dr D Strogatz, and Dr S Wing for their comments on an earlier version of the paper. We also thank $\mathrm{Mr} \mathrm{G}$ Lavoie for his collaboration in the data collection.

\section{References}

1. Brisson $C$, Vinet $A$, Vézina $M$. Disability among female garment workers: a comparison with a national sample. Scand J Work Environ Health 1989;15:323-328.

2. Comité paritaire du vêtement pour dames. Statistiques mensuelles. Montréal: Comité paritaire du vêtement pour dames, 1983-84.

3. David H, Bengle N. Le salaire au rendement. Montreal: Institut de recherche appliquée sur le travail, 1976. (Bulletin no 8.)

4. Salvendy G. Classification and characteristices of paced work. In: Salvendy G, ed. Machine pacing and occupational stress: proceedings of the international conference. London: Purdue University, 1981:5-12.

5. Berthelette $D$, Abenhaim LL. La rémunération au rendement, la santé, la sécurité du travail: recherche synthèse. Montréal: Institut de recherche en santé et sécurité du travail, 1982.

6. Cox S, Cox T, Thirlaway M, MacKay C. Effects of simulated repetitive work on urinary catecholamine excretion. Ergonomics 1982;12:1129-41.

7. Levi L. Conditions of work and sympothoadrenomedullary activity; experimental manipulations in a real life setting. Acta Med Scand 1972;191(suppl 528): $106-18$.

8. Timio M, Gentilli S, Pede S. Free adrenaline and noradrenaline excretion related to occupational stress. Br Heart J 1979;42:471-4.

9. Mairiaux P. Indicateurs physiologiques de la charge mentale; leur utilité pour le médecin du travail. Arch Mal Prof Med Trav Sec Soc 1984;2:101-10.

10. Caplan RD, Cobb S, et al. Job demands and worker health, main effects and occupational differences. Ann Arbor, MI: Institute for Social Research, The University of Michigan, 1980. (Report series.)

11. Broadbent DE, Gath D. Symptom levels in assemblyline workers. In: Salvendy G, ed. Machine pacing and occupational stress: proceedings of the international conference. London: Purdue University 1981:243-52.

12. Stammerjohn LH, Wilkes B. Stress, strain and linespeed in paced work. In: Salvendy G, ed. Machine pacing and occupational stress: proceedings of the international conference. London: Purdue University 1981:287-95.

13. Wilkes B, Stammerjohn LH, Lalich N. Job demands and worker health in machine-paced poultry inspection. Scand J Work Environ Health 1981;7(suppl 4):12-9.

14. Messing R, Riveret JP. Are women in female jobs for their health? A study of working conditions and health effects in the fish processing industry in Quebec. Int $\mathrm{J}$ Health Serv 1983;13:635-47.

15. Dessors D, Teiger C, Laville A, Gadbois C. Conditions de travail des opératices des renseignements téléphoniques et conséquences sur leur santé et leur vie personnelle et sociale. Arch Mal Prof Med Trav Séc Soc 1979: 40:469-500.

16. Billete A, Piché J. Health problems of data entry clerks and related job stressors. J Occup Med 1987;29:942-8.

17. Cohen BGF, Smith MJ, Stammerjohn LW. Psychosocial factors contributing to job stress of clerical VDT operators. In: Salvendy G, ed. Machine pacing and occupational stress: proceedings of the international conference. London: Purdue University, 1981:337-46.

18. Bureau international du travail. Les systèmes de remunération liés aux résultats. Genève: Bureau international du travail, 1980.

19. Kleinbaum DG, Kupper LL, Morgenstern H. Epidemiologic research principles and quantitative methods. Belmont, CA: Lifetime Learning Publications, 1982.

20. Wacholder S. Binomial regression in GLIM: estimating risk ratios and risk differences. Am J Epidemiol 1986; 123:174-84.

21. World Health Organization. Manual of the international classification of diseases, injuries and causes of death; 9th revision. Geneva: World Health Organization, 1977.

22. Statistical Analysis Institute Inc. Users's guide statistics. 5th edition. Cary, NC: SAS Institute Inc, 1985:403-33.

23. Baker RJ, Nelder JA. The GLIM system release 3.77 Generalised linear interactive modelling. Oxford: $\mathrm{Nu}-$ merical Algorithms Group, 1987.

24. Warren MD. Interview surveys of handicapped people: the accuracy of statements about the underlying medical conditions. Rheumatol Rehabil 1976;15:295-302.

25. Sillanpää $J$. Les conditions de travail dans l'industric du vêtement et du textile: le stress dans le travail de couture industriel. In: CSN. Les effets du travail sur la santé des travailleuses. Actes du colloque organisé par la CSN et parrainé par le BIT. Montréal: CSN 1984:69-78.

26. Teiger $C$. Táches répétitives sous contrainte de temps et charge de travail. Paris: Laboratoire de physiologie du travail et d'ergonomie du CNAM, 1973. (Rapport no 39.)

27. Vihma $T$, Nurminen $M$, Mutanen $P$. Sewing-machine 
operators work and musculoskeletal complaints. Ergonomics 1982;4:295-8.

28. Vinet $\mathrm{A}$, Brisson $\mathrm{C}$, Vezina $\mathrm{M}$. Rémunération à la pièce, travail parcellaire et santé mentale dans l'industrie du vêtement. Sociol Soc 1986;2:25-36.

29. Punnett L, Robins JM, Wegman DH, Keyserling WM. Soft tissue disorders in the upper limbs of female garment workers. Scand J Work Environ Health 1985;11: 417-25.

30. Wisner A, Laville A, Teiger C, Duraffourg J. Conséquences du travail répétitif sous cadence sur la santé des travailleurs et des accidents. Paris: Laboratoire de physiologie du travail et d'ergonomie du CNAM, 1973. (Rapport no 29 bis.)

31. Hansen NS, Jeune B. Incidence of disability pensions among slaughterhouse workers in Denmark. Scand J Soc Med 1982;10:81-5.

32. Kelsey JL. Epidemiology of musculoskeletal disorders. New York, NY: Oxford University Press 1982, chapters $1,4,6$.

Received for publication: 13 September 1988 